This work is licensed under a Creative Commons Attribution License (CC BY 4.0).

\title{
A new species of mossy frog (Anura: Rhacophoridae) from Northeastern Vietnam
}

\author{
Hoa Thi NINH ${ }^{1}$, Tao Thien NGUYEN ${ }^{\circledR 2, *}$, Huy Quoc NGUYEN ${ }^{3}$, \\ Ngoc Van HOANG ${ }^{4}$, Sonephet SILIYAVONG ${ }^{5}$, Thinh Van NGUYEN ${ }^{6}$, \\ Dzung Trung $\mathrm{LE}^{7}$, Quyet Khac $\mathrm{LE}^{8} \&$ Thomas ZIEGLER ${ }^{9}$ \\ 1,2,3 Vietnam National Museum of Nature and Institute of Genome Research,
} Vietnam Academy of Science and Technology, 18 Hoang Quoc Viet Road, Hanoi, Vietnam.

${ }^{4,5}$ Thai Nguyen University of Education, Thai Nguyen University, 20 Luong Ngoc Quyen, Thai Nguyen, Vietnam.

${ }^{6}$ Graduate University of Science and Technology, Vietnam Academy of Science and Technology, Hanoi, Vietnam.

${ }^{7}$ Ministry of Education and Training, 35 Dai Co Viet Road, Hai Ba Trung District, Vietnam. ${ }^{8}$ Center for Biodiversity Conservation and Endangered Species, 541 Nguyen Duy Trinh Street, District 2, Hochiminh City, Vietnam.

${ }^{9}$ AG Zoologischer Garten Köln, Riehler Strasse 173, D-50735 Cologne, Germany. ${ }^{9}$ Institute of Zoology, University of Cologne, Zülpicher Strasse 47B, D-50674 Cologne, Germany.

${ }^{*}$ Corresponding author: nguyenthientao@gmail.com

1ninhhoa.hnue@gmail.com

3huynguyen17295@gmail.com

4hoangngocks@dhsptn.edu.vn

${ }^{5}$ sonephet888999@gmail.com 6hopluc.cse@gmail.com

${ }^{7}$ letrungdung_sp@hnue.edu.vn

${ }^{8}$ quyet@cbes.vn

${ }^{9}$ ziegler@koelnerzoo.de

\footnotetext{
${ }^{1}$ urn:1sid:zoobank.org:author:E3D33440-C302-4B3E-9309-7310A7AA77C5

${ }^{2}$ urn:lsid:zoobank.org:author:B020706F-93E6-4A29-BB07-CA24BBF4FBFF

${ }^{3}$ urn:lsid:zoobank.org:author:0B5CC3D1-D8D5-41CD-9DC3-9F9B7FA3CE82

${ }^{4}$ urn:lsid:zoobank.org:author:5BD4C1C3-7057-4793-ADBE-69C50E540ED8

${ }^{5}$ urn:1sid:zoobank.org:author:F93E8B16-27C4-47C7-8ADB-DBECBFD7FF59

${ }^{6}$ urn:Isid:zoobank.org:author:322982AD-9202-49E4-A861-DFBA7836F09C

${ }^{7}$ urn:1sid:zoobank.org:author:2C2D01BA-E10E-48C5-AE7B-FB8170B2C7D1

${ }^{8}$ urn:lsid:zoobank.org:author:18CBF24E-0354-41CB-9903-6EE00A478934

${ }^{9}$ urn:lsid:zoobank.org:author:5716DB92-5FF8-4776-ACC5-BF6FA8C2E1BB
}

\begin{abstract}
We describe a new species of Theloderma from northeastern Vietnam based on morphological differences and molecular divergence. Theloderma khoii sp. nov. is distinguishable from its congeners on the basis of a combination of the following characters: large size, SVL $52.1 \mathrm{~mm}$ in male, $59.4 \mathrm{~mm}$
\end{abstract}


in female; head length and width equal; vomerine teeth present; snout pointed and truncated, eye large, ED $4.7 \mathrm{~mm}$ in male, $5.6 \mathrm{~mm}$ in female, spinules on upper eyelid; tibiotarsal articulation reaches to the posterior border of the eye or the tip of the snout; dorsal skin very rough with large irregular gland ridges and warts, ventral surface of body granular; tips of all digits dilated but all considerably smaller than tympanum; dorsal surface mossy green or olive mottled with dark magenta. The distribution of the new species is unknown but probably extends into adjacent high elevation forested areas in Ha Giang Province, Vietnam and in Yunnan Province, China with an extent of occurrence of only $<1000 \mathrm{~km}^{2}$ and continuing decline in the quality of its habitat due to deforestation. Thus, we suggest the species should be considered Endangered following IUCN's Red List categories.

Keywords. Theloderma khoii sp. nov., karst forest, molecular phylogeny, taxonomy, Ha Giang Province.

Ninh H.T., Nguyen T.T., Nguyen H.Q., Hoang N.V., Siliyavong S., Nguyen T.V., Le D.T., Le Q.K. \& Ziegler T. 2022. A new species of mossy frog (Anura: Rhacophoridae) from Northeastern Vietnam. European Journal of Taxonomy 794: 72-90. https://doi.org/10.5852/ejt.2022.794.1655

\section{Introduction}

The genus Theloderma Tschudi, 1838 is a poorly known group of tree frogs due to their cryptic habits and because they are infrequently encountered (Nguyen et al. 2014). This genus is currently comprised of 26 species distributed throughout Southeast Asia, southern China and northeastern India (Hou et al. 2017; Poyarkov et al. 2018; Frost 2021). Theloderma is characterized by the combination of the following morphological characters: (1) distinct tympanum, (2) rounded canthus rostralis, (3) absence of bony ridges from canthus rostralis to occiput, (4) skin of head not co-ossified to the skull, (5) having some degree of tuberculate skin, sometimes with calcified warts on the dorsum, and (6) Y-shaped terminal phalanges (Liem 1970; McLeod \& Norhayati 2007; Rowley et al. 2011; Nguyen et al. 2015, 2016; Poyarkov et al. 2015, 2018; Dever 2017; Hou et al. 2017). However, morphological synapomorphies are lacking for the genus, and the monophyly of Theloderma is not certain (Bain et al. 2009; Li et al. 2009; Rowley et al. 2011) according to the recent review by Dubois et al. (2021). Many species were described based on a single or a few specimens only, and are still imperfectly known (Stuart \& Heatwole 2004; Orlov et al. 2006; Bain et al. 2009). To date, 16 species have been recorded from Vietnam: T. albopunctatum (Liu \& Hu, 1962), until recently recorded as T. asperum (Boulenger, 1886); T. annae Nguyen, Pham, Nguyen, Ngo \& Ziegler, 2016; T. auratum Poyarkov, Kropachev, Gogoleva \& Orlov, 2018; T. bicolor (Bourret, 1937); T. corticale (Boulenger, 1903); T. gordoni Taylor, 1962; T. laeve (Smith, 1924); T. lateriticum Bain, Nguyen \& Doan, 2009; T. nebulosum Rowley, Le, Hoang, Dau \& Cao, 2011; T. palliatum Rowley, Le, Hoang, Dau \& Cao, 2011; T. petilum (Stuart \& Heatwole, 2004); T. rhododiscus (Liu \& Hu, 1962); T. ryabovi Orlov, Dutta, Ghate \& Kent, 2006; T. truongsonense (Orlov \& Ho, 2005); T. vietnamense Poyarkov, Orlov, Moiseeva, Pawangkhanant, Ruangsuwan, Vassilieva, Galoyan, Nguyen \& Gogoleva, 2015 (formerly recorded as T. stellatum Taylor, 1962) (Orlov \& Ho 2005; Orlov et al. 2006, 2012; Orlov 2007; Bain et al. 2009; Nguyen et al. 2009, 2012, 2015, 2016; Rowley et al. 2011; Poyarkov et al. 2015, 2018).

During recent field work in Ha Giang Province, northeastern Vietnam, specimens of a tree frog species were collected in deep narrow valleys within limestone mountains, between elevations of 1320 to $1750 \mathrm{~m}$ a.s.l. The area was covered by primary and secondary broadleaved karst forests. Molecular comparisons revealed that this taxon was nested within the genus Theloderma. Closer morphological examination showed that the newly discovered population from Ha Giang is clearly distinguishable from other known members of Theloderma by a combination of morphological features. The phylogenetic analyses revealed this taxon to be sister to T. bicolor with a strong support value, but being distinctly separated from it. Due to morphological and molecular differences between the newly collected specimens and all other congeneric species, we herein describe the newly discovered Theloderma population from Ha Giang as a new species. 


\section{Material and methods}

\section{Sampling}

Field surveys were conducted in June 2020 by H.Q. Nguyen and Q.K. Le in Tung Vai and Cao Ma Po Communes, Quan Ba District, Ha Giang Province, northeastern Vietnam. Specimens were collected between 19:00 and 23:30 h. After taking photographs in life, specimens were anaesthetized and euthanized in a closed vessel with a piece of cotton wool containing ethyl acetate (Simmons 2002), fixed in $80 \%$ ethanol for 4-6 hours, and then later transferred to $70 \%$ ethanol for permanent storage. Tissue samples from liver were preserved separately in $95 \%$ ethanol. Preserved specimens were deposited in the collection of the Vietnam National Museum of Nature (VNMN), Hanoi, Vietnam. Other specimens referred to in this paper (see Appendix 1) are deposited at the American Museum of Natural History (AMNH), Graduate School of Human and Environmental Studies, Kyoto University (KUHE), and Institute of Ecology and Biological Resources (IEBR), Hanoi.

\section{Morphological characters}

Measurements of preserved specimens were taken with a digital caliper to the nearest $0.1 \mathrm{~mm}$. Abbreviations are as follows:

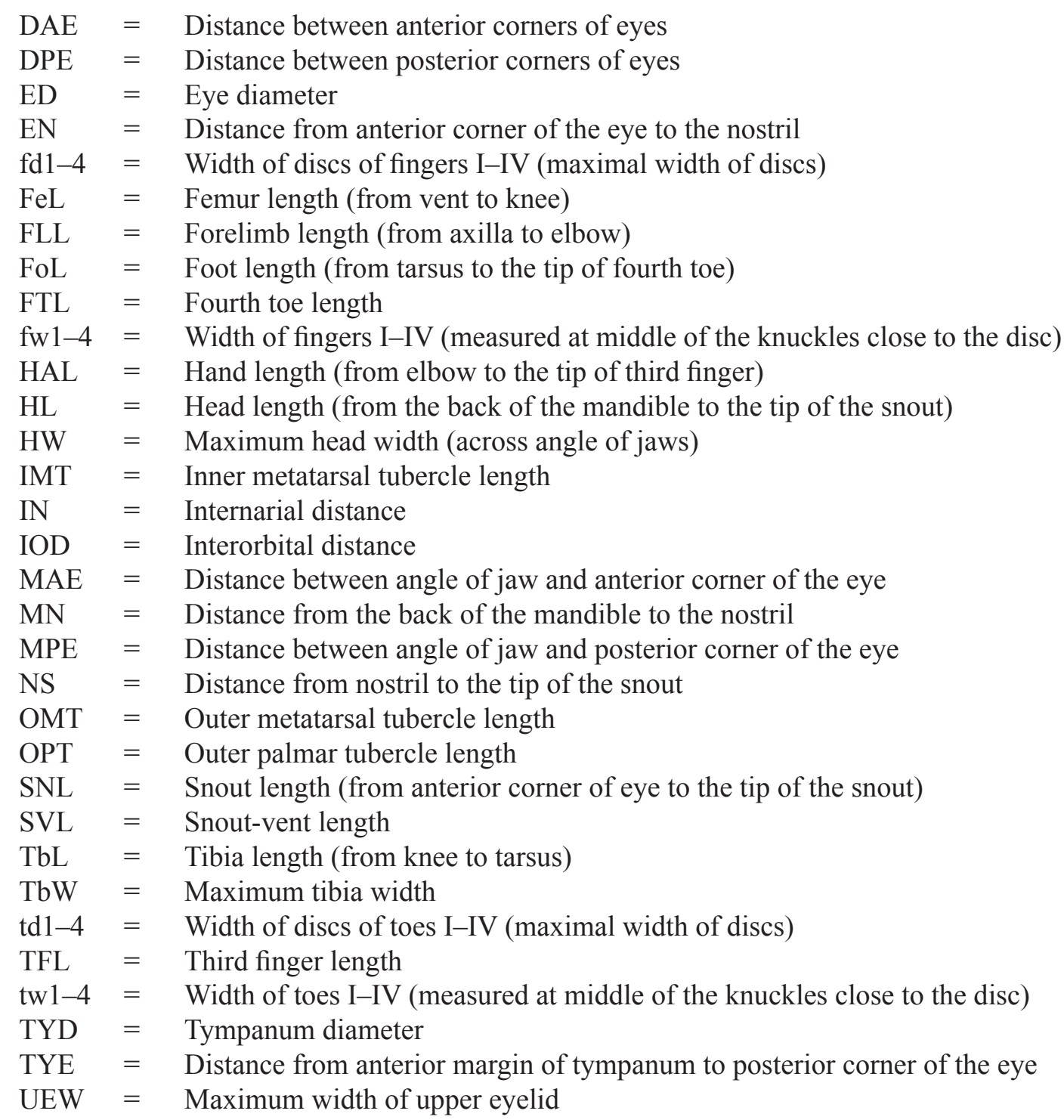


NINH H.T. et al., A new Theloderma from Vietnam

Table 1. Samples of Theloderma Tschudi, 1838 used and included in the molecular analyses.

\begin{tabular}{|c|c|c|c|c|c|}
\hline No & Species & Voucher & Locality & GenBank No. & Reference \\
\hline 1 & T. bicolor & VNMN 010811 & Lai Chau, Viet Nam & LC641699 & This study \\
\hline 2 & T. bicolor & VNMN 010821 & Lai Chau, Viet Nam & LC641700 & This study \\
\hline 3 & T. bicolor & VNMN 3536 & Lao Cai, Viet Nam & KJ802915 & Nguyen et al. 2014 \\
\hline 4 & Theloderma sp. & VNMN 012757 & Ha Giang, Viet Nam & LC641701 & This study \\
\hline 5 & Theloderma sp. & VNMN 012758 & Ha Giang, Viet Nam & LC641702 & This study \\
\hline 6 & T. corticale & DYS2 & Guangxi, China & KY495636 & Hou et al. 2017 \\
\hline 7 & T. corticale & VNMN 03556 & Vinh Phuc, Viet Nam & LC012841 & Nguyen et al. 2015 \\
\hline 8 & T. corticale & VNMN J2892 & Tuyen Quang, Viet Nam & KJ802916 & Nguyen et al. 2014 \\
\hline 9 & T. corticale & AMNH A161499 & Vinh Phuc, Viet Nam & DQ283050 & Frost et al. 2006 \\
\hline 10 & T. leporosum & LJT W46 & Malaysia & KC465841 & Li et al. 2016 \\
\hline 11 & T. leporosum & Tlep1 & Selangor, Malaysia & KT461922 & Poyarkov et al. 2015 \\
\hline 12 & T. leporosum & KUHE 52581 & Kenaboi, Malaysia & AB847128 & Matsui et al. 2014 \\
\hline 13 & T. lateriticum & AMNH 168757 & Lao Cai, Viet Nam & LC012848 & Nguyen et al. 2015 \\
\hline 14 & T. lateriticum & IEBR 3745 & Lao Cai, Vietnam & LC641703 & This study \\
\hline 15 & Nyctixalus pictus & FMNH 231094 & Sabah, Malaysia & AF458135 & Wilkinson et al. 2002 \\
\hline
\end{tabular}

Terminology for describing eye coloration in life and webbing formula followed those of Glaw \& Vences $(1997,2007)$. Sex was determined by the examination of the presence of male nuptial pads and gonadal inspection.

\section{Molecular data and phylogenetic analyses}

We used the protocols of Kuraishi et al. (2013), modified by Nguyen et al. (2015), for DNA extraction, amplification and sequencing. Fragments of three mitochondrial DNA genes, 12S rRNA, tRNA ${ }^{\text {val }}$ and 16S rRNA, were amplified using the primers following Kuraishi et al. (2013). Nyctixalus pictus (Peters, 1871) was selected as outgroup according to Nguyen et al. (2015) (Table 1).

Chromas Pro software (Technelysium Pty Ltd., Tewantin, Australia) was used to edit the sequences, which were aligned using MAFFT ver. 7 (Katoh \& Standley 2013) with default settings. We then checked the initial alignments by eye and adjusted slightly. Phylogenetic trees were constructed by using maximum likelihood (ML) and Bayesian inference (BI). Prior to ML and Bayesian analyses, we chose the optimum substitution models for entire sequences using Kakusan 4 (Tanabe 2011) based on the Akaike information criterion (AIC). The best model selected for ML was the general time reversible model (GTR: Tavaré 1986) with a gamma shape parameter (G: 0.220 in ML and 0.258 in BI). The BI summarized two independent runs of four Markov Chains for 10000000 generations. A tree was sampled every 100 generations and a consensus topology was calculated for 70000 trees after discarding the 
first 30000 trees (burn-in $=3000000$ ). We checked parameter estimates and convergence using Tracer ver. 1.5 (Rambaut \& Drummond 2009). The strength of nodal support in the ML tree was analyzed using non-parametric bootstrapping (MLBS) with 1000 replicates. We regarded tree nodes in the ML tree with bootstrap values of $70 \%$ or greater as sufficiently resolved (Huelsenbeck \& Hillis 1993), and nodes with a BPP of $95 \%$ or greater as significant in the BI analysis (Leaché \& Reeder 2002). Pairwise comparisons of uncorrected sequence divergences (p-distance) were calculated for 16S rRNA fragments only between species of the genus Theloderma.

In the preliminary analyses combining all 26 known Theloderma species and Nyctixalus pictus as outgroup, the newly discovered population from Ha Giang Province, Theloderma bicolor and T. corticale formed a clade with strong support (Bayesian posterior probability [BPP] $=95$, bootstrap support $[\mathrm{MLBS}]=89 \%)$. These results clearly suggest placement of the rhacophorid species from $\mathrm{Ha}$ Giang Province in the genus Theloderma.

Aligned, combined sequences of 16S rRNA yielded a total of 920 bp. Of 920 nucleotide sites, 219 were variable and 207 were parsimony informative within the ingroup. The ML and Bayesian analyses produced topologies with $-\operatorname{lnL}=2967.76$ and 2993.59, respectively. Phylogenetic analyses employing ML and BI methods yielded slightly different topologies only among referenced species, and only the BI tree is presented in Fig. 1. The newly discovered population of Theloderma from Ha Giang was

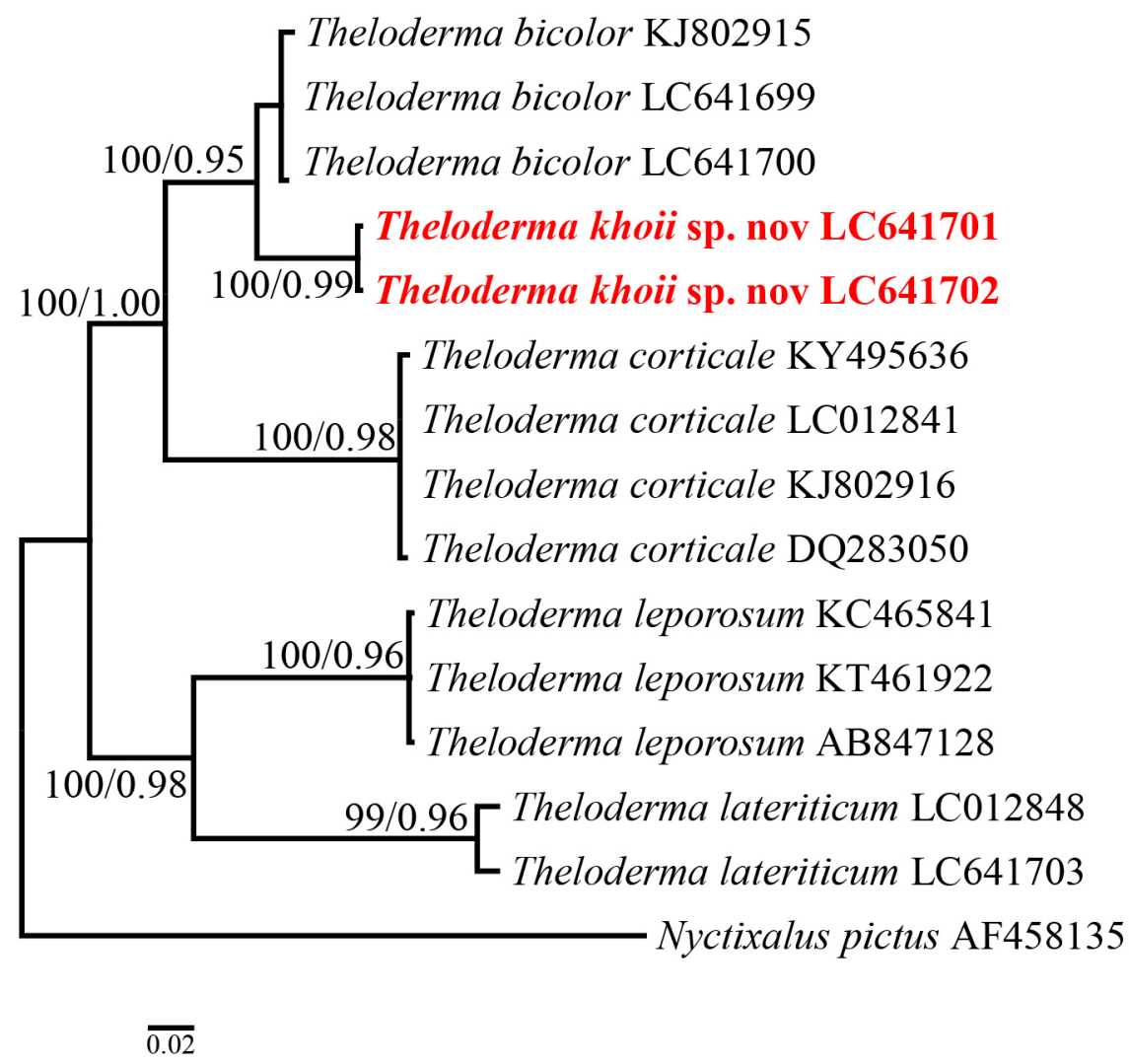

Fig. 1. BI tree from a 920 bp sequence of mitochondrial 16S rRNA gene of Theloderma Tschudi, 1838 and outgroup species. Numbers above and below branches are Bayesian posterior probabilities (values $\geq 0.95$ shown) and ML bootstrap values (values $\geq 70$ shown), respectively; for GenBank accession numbers, see Table 1 . 
Table 2. Uncorrected p-distances (\%) between species of Theloderma Tschudi, 1838 estimated from 16S rRNA sequences.

\begin{tabular}{lcccc}
\hline & 1. & 2. & 3. & 4. \\
\hline 1. Theloderma khoii sp. nov. VNMN 012757 & - & & & \\
2. T. bicolor VNMN 010821 & 4.6 & & & \\
3. T. corticale LC012841 & 11.7 & 10.8 & & \\
4. T. lateriticum IEBR 3745 & 17.1 & 14.8 & 17.50 & \\
5. T. leporosum AB847128 & 13.6 & 12.9 & 15.3 & 14.1 \\
\hline
\end{tabular}

sister to Theloderma bicolor from Lao Cai and Lai Chau provinces, Vietnam (KJ802915, LC641699, LC641700), with their monophyly being fully supported $(\mathrm{BPP}=1.00$, MLBS $=100 \%)$.

The interspecific uncorrected genetic p-distances of the fragment of 16S rRNA gene examined between the newly discovered population of Theloderma from Ha Giang and all congeners analyzed varied from approximately $4.6 \%$ (compared with $T$. bicolor) to $17.1 \%$ (compared with T. lateriticum).

This degree of pairwise divergence in the 16S rRNA gene in frogs has been interpreted previously as indicative of differentiation at the species level (Vences et al. 2005). Furthermore, the new population is also clearly separated morphologically from all nominal species of Theloderma. Thus, we conclude that the rhacophorid species from Ha Giang, Vietnam is a distinct species in the genus Theloderma.

\title{
Results
}

\author{
Class Amphibia Gray, 1825 \\ Order Anura Fischer von Waldheim, 1813 \\ Family Rhacophoridae Hoffman, 1932 \\ Genus Theloderma Tschudi, 1838 \\ Theloderma khoii sp. nov. \\ urn:lsid:zoobank.org:act:491C280C-F0CA-475E-8DC9-377603DCA558
}

Figs 2-3

\section{Diagnosis}

Theloderma khoii sp. nov. shows the diagnostic characters of the genus Theloderma, for instance a distinct tympanum, round canthus rostralis, bony ridges from canthus rostralis to occiput absent, and skin of head not co-ossified to the skull, and also molecular analyses revealed it to be nested within Theloderma. The new species is distinguished from its congeners and other small rhacophorid species by a combination of the following characters: 1) large-sized frog of the genus Theloderma (SVL $52.2 \mathrm{~mm}$ in a single male, $59.4 \mathrm{~mm}$ in a single female); 2) head length and width equal; 3) vomerine teeth present; 4) snout pointed and truncated (SNL/SVL $16.3 \%$ in male; $16.0 \%$ in female); 5) eye large, eye diameter about a half of snout length (ED/SNL $54.60 \%$ in male; $58.9 \%$ in female), spinules on upper eyelid; 6) tibiotarsal articulation reaching to the posterior border of the eye or the tip of the snout; 7) dorsal skin very rough, with large irregular gland ridges and warts, ventral surface granular; 8) fingers rudimentary webbed, toes almost four-fifths webbed, tips of all digits dilated but all considerably smaller than 
tympanum; 9) dorsal surface mossy green or olive mottled with dark magenta; 10) lateral and ventral surfaces black with irregular lemon yellow pattern and some white granules; 11) male with large nuptial pads and an inner vocal sac.

\section{Etymology}

The specific epithet is in honor of Professor Dr Le Vu Khoi of the VNU Hanoi University of Science, Ha Noi, Vietnam, in recognition of his great support of teaching, mentoring, research and conservation work in Vietnam. As common names we suggest Khoi’s Mossy Frog (English) and Êch cây sần khôi (Vietnamese).

\section{Type material}

Holotype

VIETNAM • adult $\widehat{O}$; northern Vietnam, Ha Giang Province, Quan Ba District, in the karst forest near Tung Vai Commune; 1641 m a.s.1; 8 Jun. 2020; H.Q. Nguyen leg.; VNMN 012757.

\section{Paratype}

VIETNAM • adult $\$$; same collection data as for holotype; VNMN 012758.

\section{Description}

\section{Holotype}

Size. Large, body distinctly flattened (SVL $52.2 \mathrm{~mm}$ ).

HEAD. Very strongly depressed, length and width equal (HL $19.7 \mathrm{~mm}$, HW $19.7 \mathrm{~mm}$ ), snout pointed and truncated, snout length double the diameter of eye (SNL $8.5 \mathrm{~mm}$, ED $4.7 \mathrm{~mm}$ ).

Canthus rostralis. Oval, loreal region very oblique, slightly concave; interorbital distance wider than internarial distance and upper eyelid width (IOD $6.0 \mathrm{~mm}$, IN $3.7 \mathrm{~mm}$, UEW $4.5 \mathrm{~mm}$ ); distance between anterior corners of eyes (DAE $10.1 \mathrm{~mm}$ ) about $59.8 \%$ distance between posterior corners of eyes (DPE $16.3 \mathrm{~mm}$ ).

NostriL. Oval, inside rather enlarged tubercle on tip of snout, nostrils nearer to tip of snout than to eyes (NS $3.1 \mathrm{~mm}$, EN $6.1 \mathrm{~mm}$ ).

PupIL. Circular.

Tympanum. Distinct, diameter less than eye diameter and slightly larger than width of third finger disc (TYD $3.7 \mathrm{~mm}$ ), tympanum separated from eye by distance (TYE) $65.0 \%$ of tympanum length (TYD).

Pineal ocellus. Absent; conical tubercles on eyelid, smaller than those in the back.

SUPRATYMPANIC FOLD. Distinct, interrupted, extending from behind eye to beyond level of axilla, composed of large irregular glandular ridges.

Vomerine TEETH. Arranged in two small oblique groups between choanae and widely separated from each other.

Tongue. Large, accounting for almost half of mouth, heart-shaped, dorsal surface smooth, notched and free posterior.

ForeLIMBS. Moderately strong and long (FLL $13.2 \mathrm{~mm}$, HAL $15.1 \mathrm{~mm}, 54.3 \%$ of SVL), much shorter than hindlimbs (FLL $87.5 \%$ of HAL); relative length of fingers: I $<$ II $<$ IV $<$ III; tips of fingers dilated into 
large, rounded and flattened discs, with grooves separating dorsum of discs from venter; disc of finger III approximately two times width of finger III (fd3/fw3 219.2\%) but smaller than tympanum diameter (fd3/TYD 83.1\%); subarticular tubercles large and distinct, with indistinct supernumerary tubercles; formula of subarticular tubercles: 1, 1,2,2; well-developed nuptial pad on lateral side of thumb; outer side of fourth finger fringed, outer edge of fourth finger distinctly serrated; webbing between fingers slightly developed, about $50 \%$ between base of finger up to proximal subarticular tubercles (Fig. 3).

HinDLIMBS. Strong and long, tibia length about five times greater than tibia width (TbL $27.3 \mathrm{~mm}$, TbW $5.65 \mathrm{~mm}$, TbL/TbW 4.6), tibia longer than thigh length and foot length (TbL/FeL 107\%; TbL/ FoL 108\%), tibio-tarsal articulation reaching posterior edge of snout when hindlimbs pressed forward as opposed to eye; relative length of toes I $<$ II $<$ V $<$ III $<$ IV; toes with rounded discs, tips of toes dilated into flattened discs with grooves that separate dorsum from venter, smaller than discs on fingers; webbing formula I(1/3) - (1)II(0) - (1/2)III(0) - (1)IV(1) - (1/3)V (Fig. 3); large subarticular tubercles roundish: 1, 1, 2, 3, 2; large inner metatarsal tubercle oval and raised (IMT $2.7 \mathrm{~mm}$ ), outer metatarsal tubercle absent; with small warts on inner aspect of metatarsal area; outer side of fifth toe fringed, outer edge of fringe with five distinct serrations.

SKIN TEXTURE IN LIFE. Dorsal surface of head, dorsum, arms and legs above very rough, with large irregular glandular ridges ordered symmetrically in middle vertebral region; a large, distinct horn gland behind head in X-shape; on top of each supraorbital 3-4 enlarged glands, distinctly conical; lateral parts of body become granular; large conical tubercles on back of thighs near vent; throat and chest with some small blurred pattern; belly and ventral surface and underside of thigh with thickened flat granules or

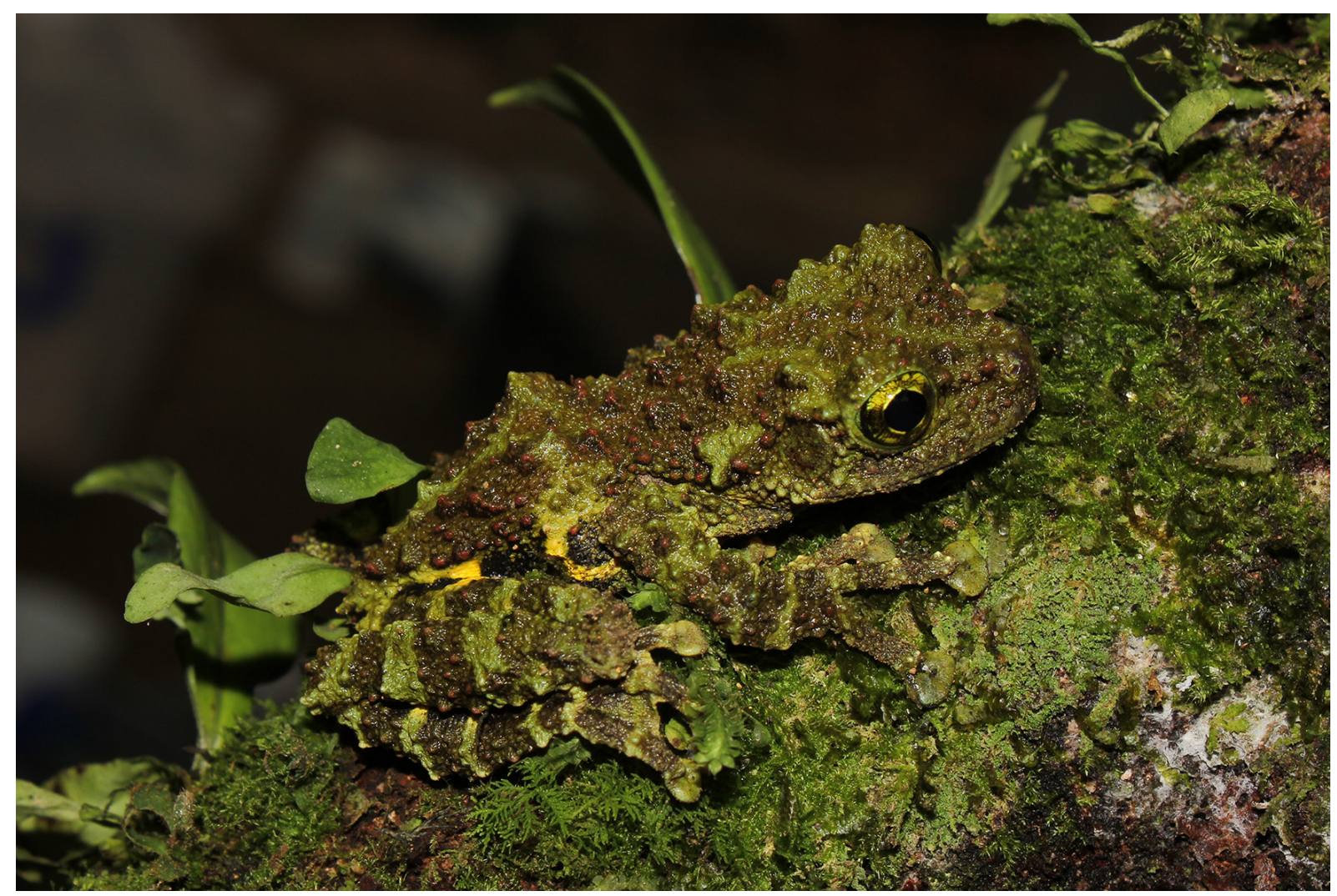

Fig. 2. Theloderma khoii sp. nov., holotype, ổ (VNMN 012757). Dorsolateral view, in life. 
warts on groin; axillary region and underside of tibia smooth; surroundings of tympanum with small tubercles, with 4-5 enlarged tubercles posteriorly.

Coloration IN LIFE. Dorsal surface mossy-green or light-olive mixed with mossy-green, resembling moss; tips of skin ridges and tubercles reddish-brown; flank with clearly shaped dark brown pattern, ventrally joining a yellowish-green band; dorsal surfaces of forelimbs and hindlimbs with army-green bands, and some irregular patches on webbing; both finger and toe discs green, in center deep olive; nuptial pad ivory; throat and chest dark-brown with yellowish-green warts; belly has black shape of irregular size with yellowish-green pattern and some cream warts; pupil black, iris yellowish-green with irregular black reticulation; tympanum dark-olive (Fig. 2).

COLORATION IN PRESERVATIVE. In ethanol, dorsal surfaces of head, dorsum, and upper part of flanks dark indigo with brown markings and blotches; tympanum light brown; forelimb, dorsal surface of thigh, tibia and foot black with lights bands, posterior part of thigh below vent dark-grey with large ivory bands; chin and throat light-grey with small ivory spots; chest and belly dark to black, with cream areas on chest (Fig. 3).

\section{Variation of paratype}

Male smaller than female, with single vocal sac and nuptial pads. For measurements of the type series see Table 3.

\section{Comparison with other species}

We compared Theloderma khoii sp. nov. with other members of the genus Theloderma based on morphological specimen examination (see Appendix 1) and data obtained from the literature (e.g., Tschudi 1838; Boulenger 1903; Smith 1924; Ahl 1927, 1931; Bourret 1937, 1942; Liu \& Hu 1962; Taylor 1962; Chanda 1994; Inger et al. 1999; Chanard 2003; Bain \& Nguyen 2004; Stuart \& Heatwole

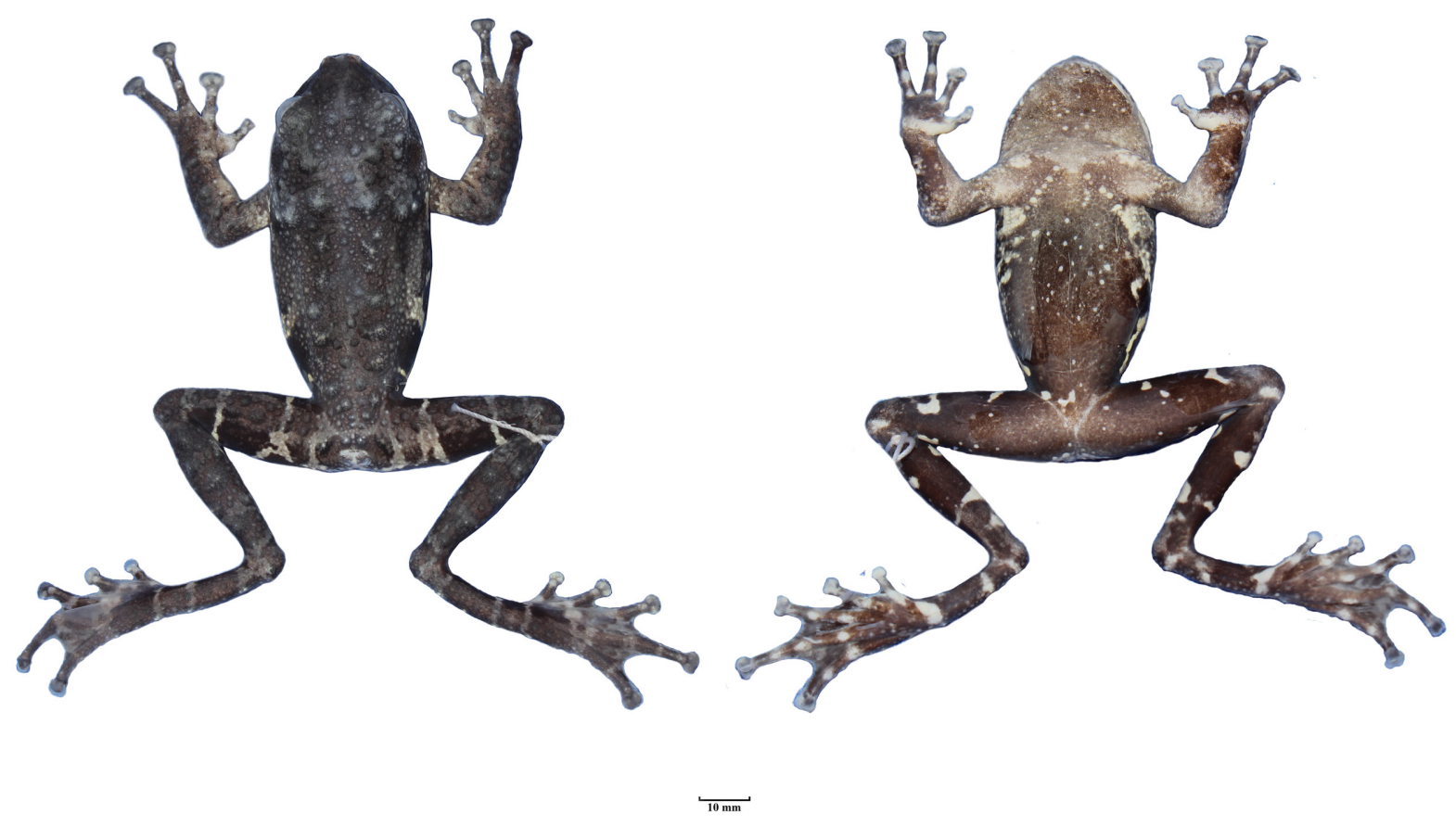

Fig. 3. Theloderma khoii sp. nov., holotype, §̊ (VNMN 012757). Dorsal (left) and ventral view (right) during fixation. 
Table 3. Measurements (in $\mathrm{mm}$ ) and proportions of the type series of Theloderma khoii sp. nov. (for abbreviations see Material and methods).

\begin{tabular}{lccccc}
\hline & VNMN & VNMM & & VNMN & VNMM \\
& $\mathbf{0 1 2 7 5 7}$ & $\mathbf{0 1 2 7 5 8}$ & & $\mathbf{0 1 2 7 5 7}$ & $\mathbf{0 1 2 7 5 8}$ \\
\hline & $\begin{array}{c}\text { 1 } \\
\text { holotype }\end{array}$ & $\begin{array}{c}\text { + } \\
\text { paratype }\end{array}$ & & $\begin{array}{c}\text { \% } \\
\text { holotype }\end{array}$ & $\begin{array}{c}+ \\
\text { paratype }\end{array}$ \\
\hline SVL & 52.2 & 59.4 & TYD & 3.7 & 4.0 \\
HW & 19.7 & 20.7 & TYE & 2.4 & 2.6 \\
HL & 19.7 & 21.5 & FLL & 13.2 & 14.7 \\
MN & 18.5 & 19.4 & HAL & 15.1 & 19.6 \\
MFE & 13.1 & 14.0 & TFL & 3.54 & 5.54 \\
MBE & 8.8 & 8.7 & fd3 & 3.2 & 4.2 \\
SNL & 8.5 & 9.5 & FeL & 25.6 & 27.1 \\
ED & 4.6 & 5.6 & TbL & 27.3 & 29.6 \\
UEW & 4.5 & 5.7 & TbW & 6.0 & 7.0 \\
IN & 3.7 & 3.6 & FoL & 25.3 & 27.2 \\
IOD & 6.1 & 5.5 & FTL & 25.1 & 26.9 \\
DAE & 10.1 & 11.8 & SNL/SVL & $16.3 \%$ & $16.0 \%$ \\
DPE & 16.3 & 17.7 & ED/SNL & $54.6 \%$ & $58.9 \%$ \\
NS & 3.0 & 2.9 & TYE/TYD & $65.1 \%$ & $63.6 \%$ \\
EN & 6.1 & 6.2 & fd3/TYD & $83.1 \%$ & $76.5 \%$ \\
\hline
\end{tabular}

2004; Orlov \& Ho 2005; Orlov et al. 2006, 2012; McLeod \& Norhayati 2007; Bain et al. 2009; Chan \& Norhayati 2009; Fei et al. 2009, 2012; Jiang et al. 2009; Kunz et al. 2010; Rowley et al. 2011; Nguyen et al. 2014).

Species of Theloderma inhabiting Indochina, Sumatra, southern China and eastern India can be assigned to three different size groups (Dever 2017): small species (SVL $<35 \mathrm{~mm}$ ), such as T. albopunctatum (Liu \& Hu, 1962); T. annae Nguyen, Pham, Nguyen, Ngo \& Ziegler, 2016; T. asperum (Boulenger, 1886); T. auratum Poyarkov, Kropachev, Gogoleva \& Orlov, 2018; T. baibungense Jiang, Fei \& Huang, 2009; T. lacustrinum Sivongxay, Davankham, Phimmachak, Phoumixay \& Stuart, 2016; T. laeve (Smith, 1924); T. lateriticum Bain, Nguyen \& Doan, 2009; T. licin McLeod \& Ahmad, 2007; T. nebulosum and T. palliatum Rowley, Le, Hoang, Dau \& Cao, 2011; T. petilum (Stuart \& Heatwole, 2004); T. pyaukkya Dever, 2017; T. rhododiscus (Liu \& Hu, 1926); T. (Stelladerma in Poyarkov et al. 2015) stellatum Taylor, 1926; T. (Stelladerma in Poyarkov et al. 2015) vietnamense (Poyarkov et al., 2015); and T. truongsonense (Orlov \& Ho, 2005); medium-sized species with SVL of 40-45 mm, T. horridum (Boulenger, 1903); T. moloch (Annandale, 1912); T. phrynoderma (Ahl, 1927); T. nagalandense and T. ryabovi Orlov, Dutta, Ghate \& Kent, 2006; and T. schmardana (Kelaart, 1853); large-sized species with SVL 48-75 mm (Orlov 1997), including T. bicolor (Bourret, 1937); T. corticale (Boulenger, 1903); T. gordoni Taylor, 1962; T. leporosum Tschudi, 1838; and Theloderma khoii sp. nov.

Compared to T. bicolor, another large-sized group member in Vietnam, Theloderma khoii sp. nov. can be distinguished by its coloration pattern: the lateral part from the axilla to groin is black with an irregular yellowish-green pattern in T. bicolor vs flank pattern with clear brown-dark speckles, ventrally joining the yellowish-green band in Theloderma khoii sp. nov.; a comparatively lighter belly pattern, consisting 
of irregular blackish brown speckles with whitish pattern in $T$. bicolor vs belly irregular black with yellowish-green pattern and some cream warts, and the presence of few smaller bluish spots on the throat, in Theloderma khoii sp. nov. (Fig. 4); by the comparatively dark-colored posterior part of the thighs, consisting of black blotches and irregular light-green or olive reticulations (vs black with yellowgreenish bands and a few red-brown warts in Theloderma khoii sp. nov.; Fig. 4); and foot webbing well-developed: I(0) - (1)II(0) - (1/2)III(0) - (1)IV(1) - (0)V (vs I(1/3) - (1)II(0) - (1/2)III(0) - (1) IV(1)-(1/3)V in Theloderma khoii sp. nov.; Fig. 4). Theloderma khoii sp. nov. (Bourret 1937; Hou et al. 2017) differs from T. corticale by its shorter body size: SVL $52.2 \mathrm{~mm}$ in male and $59.4 \mathrm{~mm}$ in female
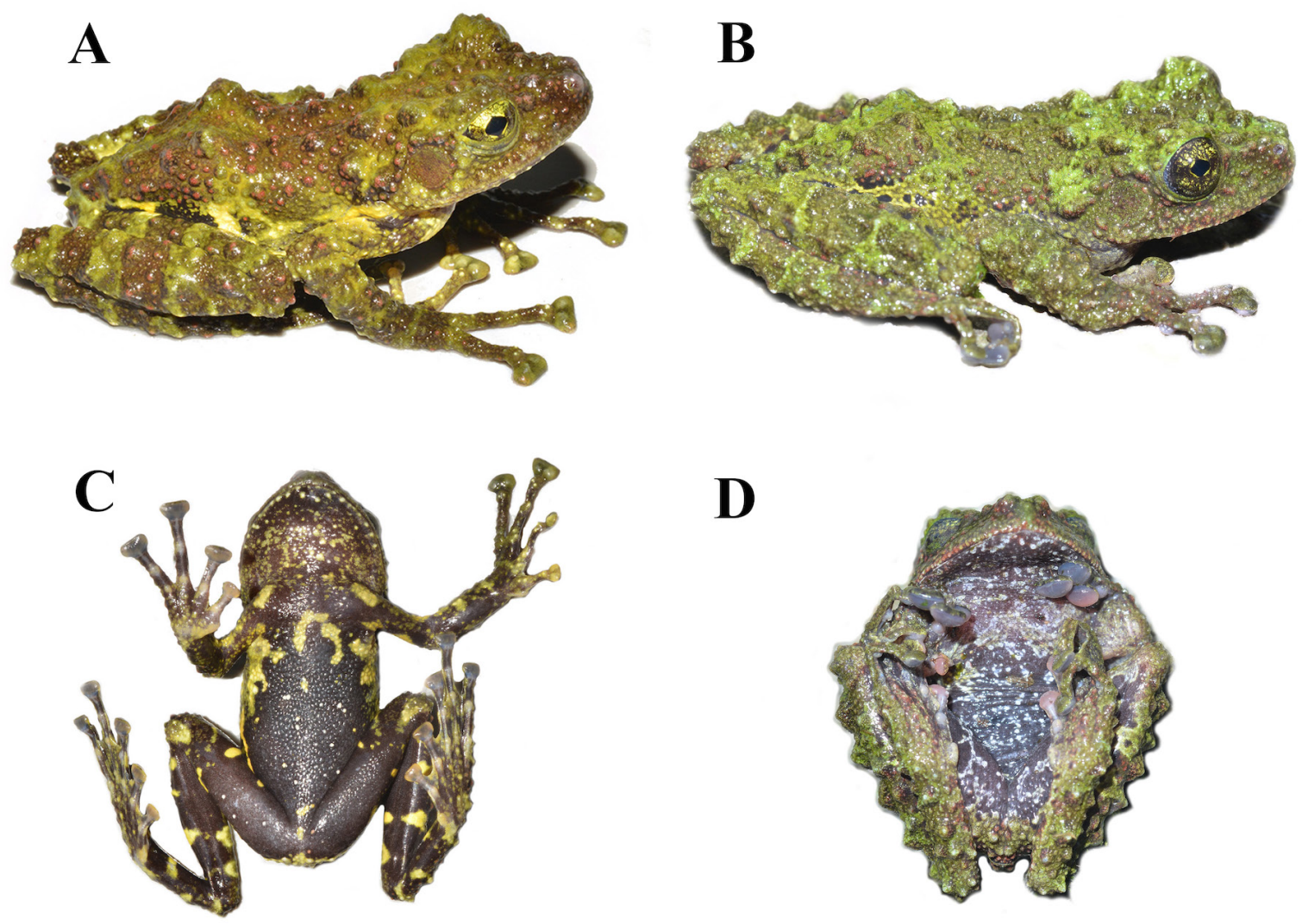

D
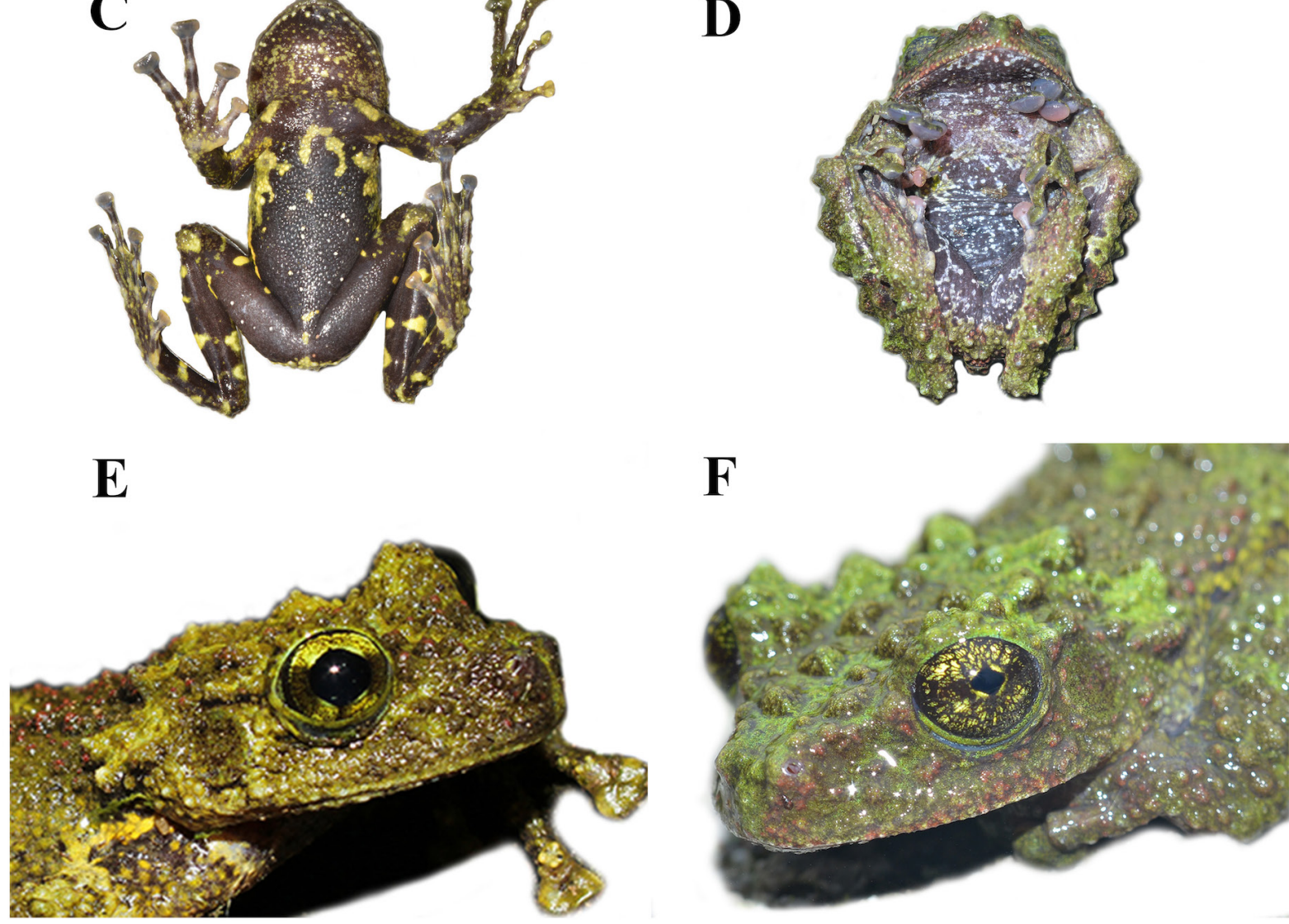

Fig. 4. A, C, E. Theloderma khoii sp. nov., holotype, ${ }^{\Uparrow}$ (VNMN 012757). B, D, F. Theloderma bicolor (Bourret, 1937) (VNMN 010811). Dorsal (A-B) and ventral views (C-D) as well as lateral head (E-F). 
in Theloderma khoii sp. nov. vs SVL up to $67 \mathrm{~mm}$ in $T$. corticale; by colour pattern: a much lighter belly pattern, yellow-lemon with irregular small black patterns and creamy warts (vs dark belly pattern, blackish ground color with thin yellowish-green pattern and some cream warts in Theloderma khoii sp. nov.); by skin texture: the absence of enlarged warts in the scapular area (vs large irregular prominent warts on dorsum, forming large groups at the base of the head and scapular area in Theloderma khoii sp. nov.); by the head being slightly wider than long (vs head length and width equal in Theloderma khoii sp. nov.); and foot webbing well developed: webbing formula: $\mathrm{I}(0)-(1+12) \mathrm{II}(0)-(1) \operatorname{III}(0)-(1)$ $\mathrm{IV}(1)-(0) \mathrm{V}(\mathrm{vs} \mathrm{I}(1 / 3)-(1) \mathrm{II}(0)-(1 / 2) \mathrm{III}(0)-(1) \mathrm{IV}(1)-(1 / 3) \mathrm{V}$ in Theloderma khoii sp. nov.

Theloderma khoii sp. nov differs from T. gordoni by its coloration pattern: dorsal surface mossy-green or light-olive mixed with mossy-green, resembling moss; ventral yellowish-green band in Theloderma khoii sp. nov. vs dorsum dark brown or coffee with some clusters light brown or orange on enlarged gland ridges; ventral surface dark blue with numerous irregular grayish white patterns and speckles in T. gordoni. Tympanum and tympanic fold distinct in Theloderma khoii sp. nov. vs tympanum and tympanic fold invisible in T. gordoni; head width equal to head length in Theloderma khoii sp. nov. vs head width greater than head length in T. gordoni (Qui et al. 2018).

\section{Ecological notes}

Theloderma khoii sp. nov. appears to be closely associated with karstic environments. Specimens were found at night between 19:00 and 23:30 h near cave entrances and in valleys surrounded by limestone cliffs, about 5-6 m from water sources (Fig. 5). Advertisement calls, eggs and tadpoles of the species have not been recorded during our field surveys. The main habitat at the type locality was secondary

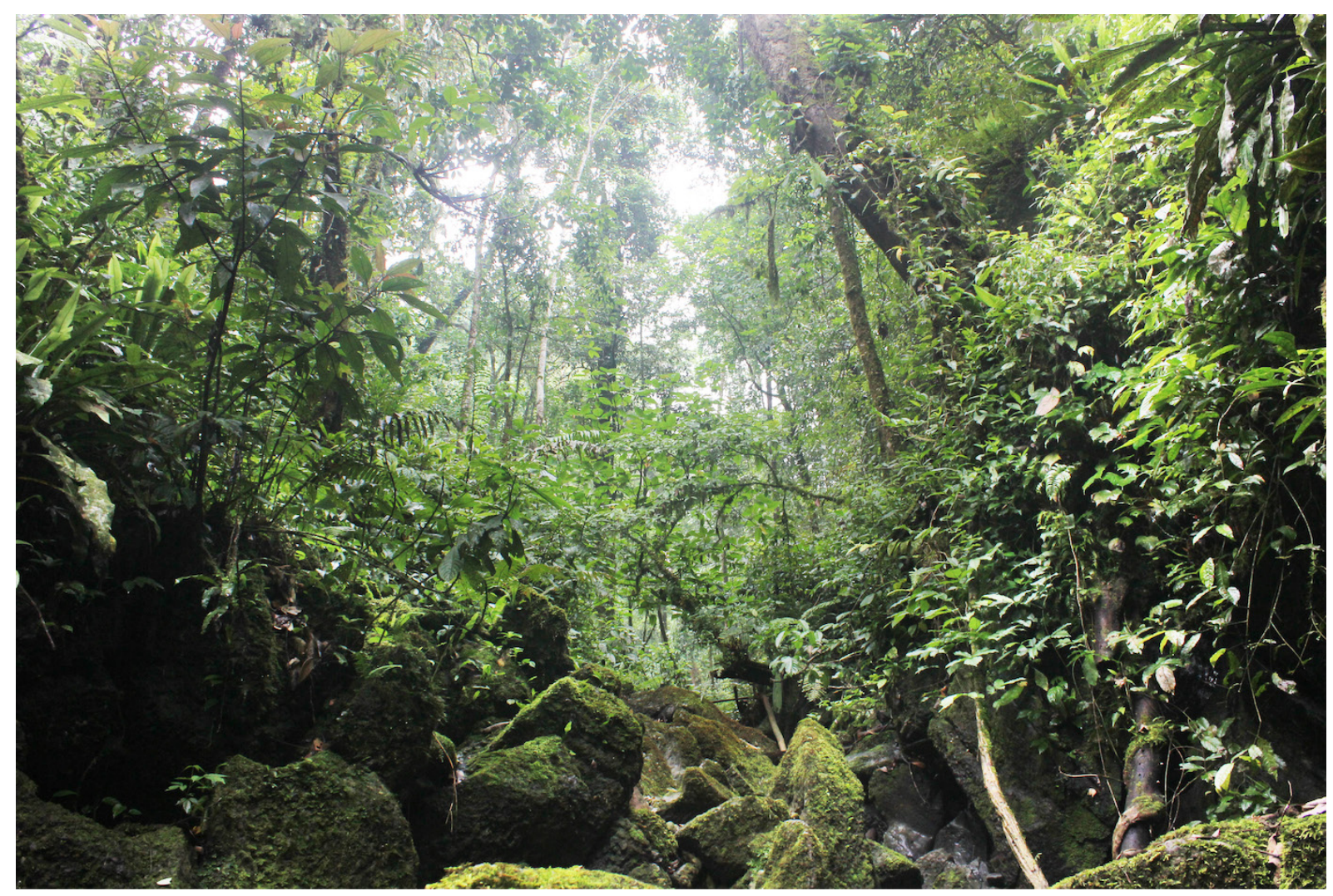

Fig. 5. Habitat of Theloderma khoii sp. nov. at the type locality in Quan Ba District, Ha Giang Province, Northern Vietnam. 
karst forest of medium and small hardwoods mixed with shrubs and vines. One specimen was found on a leaf, about $0.5-1.2 \mathrm{~m}$ above the ground, the other specimen was collected on a limestone cliff, about $0.5-1.2 \mathrm{~m}$ above the ground. The air temperature at the time of collection ranged from 18.3 to $23.2^{\circ} \mathrm{C}$ and relative humidity from 91 to $100 \%$. In Tung Vai, several species of Theloderma have been recorded, viz. T. albopunctatum (Liu \& Hu, 1962), T. gordoni (Taylor, 1962), T. lateriticum (Bain, Nguyen \& Doan, 2009), and T. rhododiscus (Liu \& Hu, 1962), but all were found in tree holes filled with water or on tree leaves near streams in the valleys. Other tree frogs that were found at the same site were Polypedates sp. (of the P. megacephalus Hallowell, 1861 species complex), Zhangixalus duboisi (Ohler, Marquis, Swan \& Grosjean, 2000), Z. jodiae Nguyen, Ninh, Orlov, Nguyen \& Ziegler, 2020, Z. franki Ninh, Nguyen, Orlov, Nguyen \& Ziegler, 2020, Z. pachyproctus Yu, Hui, Hou, Wu, Rao \& Yang, 2019 and Kurixalus sp.

\section{Distribution}

Theloderma khoii sp. nov. is currently known only from the type locality in Ha Giang Province, northeastern Vietnam (Fig. 6). The species was recorded at elevations between 1320 and $1750 \mathrm{~m}$ a.s.1.

\section{Conservation status}

The range of the new species is not expected to extend outside of Mount Tung Vai and it is expected to be found in evergreen forests of Yunnan Province, southern China. However, the actual distributional range should be the focus of further studies. Currently, we assume that the new species is restricted geographically, likely having an Extent Of Occurrence (EOO) of only $<1000 \mathrm{~km}^{2}$. The new species likely occurs in one threat-defined location, which has been characterized as an area with a continuing decline in the quality of its habitat due to deforestation (Meyfroidt et al. 2013). Therefore, Theloderma khoii sp. nov. likely qualifies as Endangered (EN) B1ab(iii) in accordance with the categories and criteria of the IUCN Red List of Threatened Species (IUCN 2012).

\section{Discussion}

In our phylogenetic analysis, Theloderma khoii sp. nov. is sister to T. bicolor, from which it differed by a $4.6 \%$ genetic divergence in fragments of the $16 \mathrm{~S}$ gene (Table 2). The distribution range of $T$. bicolor encompasses the west of the Red River including northwestern Vietnam (Lai Chau and Lao Cai provinces), and also Jingdong and Luechun counties, central and southeastern Yunnan, China (Frost 2021), whereas Theloderma khoii sp. nov. is currently only known from Ha Giang Province, north of the Red River (Fig. 6). The discovery of Theloderma khoii sp. nov. supports the hypothesis that the Red River is a barrier to gene flow and dispersal (Zhi et al. 2016).

Morphologically, Theloderma khoii sp. nov. can clearly be distinguished from other members of Theloderma in having the dorsal surface being green or olive with mossy markings. The moss-green coloration on the dorsal surface of the new species, which can blend remarkably well into the background of stones covered with lichens or tree leaves, seems to be an adaptation to the life mode associated with the karst environment (Nguyen et al. 2016). The rich biodiversity of karst forests in Tung Vai as well as elsewhere in northeastern Vietnam is currently under threat due to the effects of border road construction, expanding agriculture, and illegal timber logging (Bain \& Nguyen 2004; Ziegler et al. 2014; Nguyen et al. 2018).

Vietnam has more Theloderma species than any other country; a total of 16 species have been recorded to date (Frost 2021). The discovery of an additional species of Theloderma in Vietnam suggests that the current species richness of the genus remains underestimated. More studies using an integrative approach, i.e., combining morphological and molecular data, will help to reveal the extent of species richness of Theloderma in the poorly studied regions of northern Vietnam. 


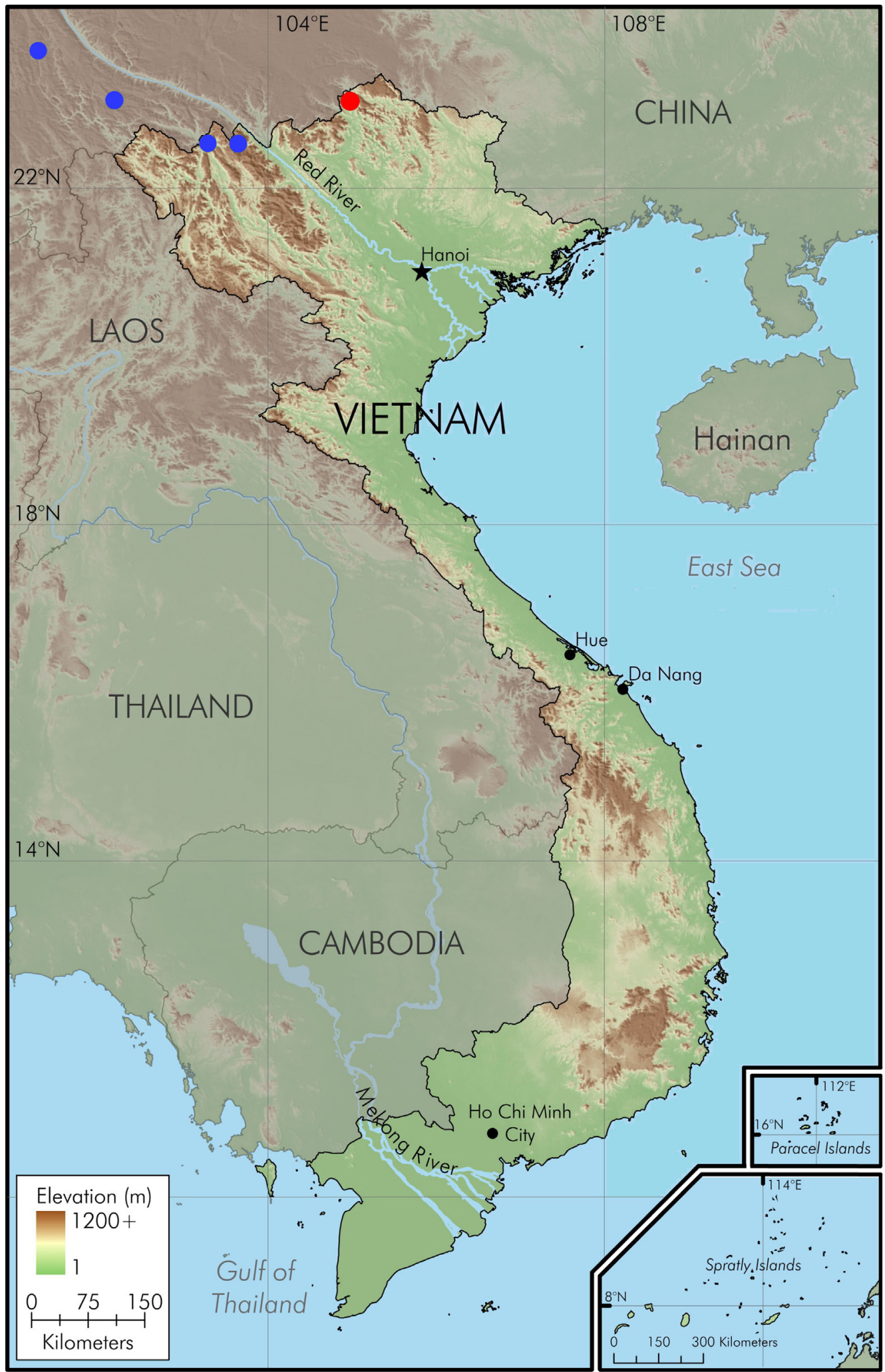

Fig. 6. Map showing distribution of Theloderma bicolor (Bourret, 1937) (blue circles) in Lao Cai and Lai Chau provinces, Vietnam and Jingdong and Luechun counties, Yunnan Province, China (west of the Red River) and the type locality (red circle) of Theloderma khoii sp. nov. in Ha Giang Province, Vietnam (north of the Red River). 


\section{Acknowledgements}

We are grateful to the directorates of the Forest Protection Department of Ha Giang Province for support of our field work and issuing relevant permits. We thank M.V. Le, Mr Chu Xuan Canh (Fauna \& Flora International - Vietnam Programme) and the members of community based conservation teams of Cao Ma Po, Ta Van and Tung Vai Communes, Quan Ba District for their assistance in the field. We thank E. Sterling (New York) and K. Koy (Berkeley) for providing the map. The research of T.T. Nguyen is funded by the Vietnam National Foundation for Science and Technology Development (NAFOSTED) under Grant Number 106.05-2019.334. Field work in Ha Giang Province was partially funded by the Minister of Education and Training (B2021-TNA-20) for N.V. Hoang, and by the Vietnam Academy of Science and Technology (NVCC33.06/21-21) for T.T. Nguyen.

\section{References}

Ahl E. 1927. Zur Systematik der asiatischen Arten der Froschgattung Rhacophorus. Sitzungsberichte der Gesellschaft Naturforschender Freunde zu Berlin 1927: 35-47.

Ahl E. 1931. Amphibia, Anura III, Polypedatidae. Das Tierreich 55: 1-477. https://doi.org/10.1515/9783111625430

Bain R.H. \& Nguyen T.Q. 2004. Herpetofaunal diversity of Ha Giang Province in northeastern Vietnam, with descriptions of two new species. American Museum Novitates 3453: 1-42.

https://doi.org/10.1206/0003-0082(2004)453<0001:HDOHGP>2.0.CO;2

Bain R.H., Nguyen T.Q. \& Doan K.V. 2009. A new species of the genus Theloderma Tschudi, 1838 (Anura: Rhacophoridae) from northwestern Vietnam. Zootaxa 2191 (1): 58-68. https://doi.org/10.5281/zenodo.189385

Boulenger G.A. 1903. Descriptions of three new batrachians from Tonkin. Annals and Magazine of Natural History, Series 7 12: 186-188. https://doi.org/10.1080/00222930308678835

Bourret R. 1937. Notes herpétologiques sur l'Indochine française. XIV. Les batraciens de la collection du Laboratoire des Sciences Naturelles de l'Université. Descriptions de quinze especes ou variétés nouvelles. Annexe au Bulletin Général de l'Instruction Publique, Hanoi 4: 5-56.

Bourret R. 1942. Les Batraciens de l'Indochine. Institut Océanographique de l'Indochine, Hanoi.

Chan K.O. \& Norhayati A. 2009. Distribution and natural history notes on some poorly known frogs and snakes from Peninsular Malaysia. Herpetological Review 40: 294-301.

Chanard T. 2003. A Photographic Guide to Amphibians in Thailand. Darnsutha Press, Bangkok.

Chanda S.K. 1994. Anura (Amphibia) of north-eastern India. Memoirs of the Zoological Survey of India 18: $1-143$.

Dever J.A. 2017. A new cryptic species of the Theloderma asperum complex (Anura: Rhacophoridae) from Myanmar. Journal of Herpetology 51 (3): 425-436. https://doi.org/10.1670/17-026

Dubois A., Ohler A. \& Pyron A. 2021. New concepts and methods for phylogenetic taxonomy and nomenclature in zoology, exemplified by a new ranked cladonomy of recent amphibians (Lissamphibia). Megataxa 5 (1): 1-738. https://doi.org/10.11646/megataxa.5.1.1

Fei L., Hu S., Ye C. \& Huang Y. 2009. Fauna Sinica. Amphibia. Volume 2. Anura. Science Press, Beijing.

Fei L., Ye C. \& Jiang J. 2012. Colored Atlas of Chinese Amphibians. Sichuan Publishing Group, Chengdu, China.

Frost D.R. 2021. Amphibian Species of the World: an Online Reference. Version 6.1. American Museum of Natural History, New York. https://doi.org/10.5531/db.vz.0001 
Frost D.R., Grant T., Faivovich J., Bain R.H., Haas A., Haddad C.F.B., De S.R.O., Channing A., Wilkinson M., Donnellan S.C., Raxworthy C.J., Campbell J.A., Blotto B.L., Moler P., Drewes R.C., Nussbaum R.A., Lynch J.D., Green D.M. \& Wheeler W.C. 2006. The amphibian tree of life. Bulletin of the American Museum of Natural History 297: 1-370. https://doi.org/10.5531/sd.sp.13

Glaw F. \& Vences M. 1997. Anuran eye colouration: definitions, variation, taxonomic implication and possible functions. In: Böhme W., Bischoff W. \& Ziegler T. (eds) Herpetologia Bonnensis: Proceedings of the $8^{\text {th }}$ Ordinary General Meeting of the Societas Europaea Herpetologica: 125-138. Bonn, Germany.

Glaw F. \& Vences M. 2007. A Field Guide to the Amphibians and Reptiles of Madagascar. Third Edition, Frosch Verlag, Cologne.

Hou M., Yu G., Chen H., Liao C., Zhang L., Chen J., Li P. \& Orlov N.L. 2017. The taxonomic status and distribution range of six Theloderma species (Anura: Rhacophoridae) with a new record in China. Russian Journal of Herpetology 24: 99-127. https://doi.org/10.30906/1026-2296-2019-24-2-99-127

Huelsenbeck J.P. \& Hillis D.M. 1993. Success of phylogenetic methods in the four-taxon case. Systematic Biology 42: 247-264. https://doi.org/10.1093/sysbio/42.3.247

Inger R.F., Orlov N.L. \& Darevsky I. 1999. Frogs of Vietnam: a report on new collections. Fieldiana, Zoology 92: 1-46. https://doi.org/10.5962/bhl.title.3478

IUCN 2012. The IUCN Red List of Threatened Species. Version 2012.2. Available from http://www.iucnredlist.org [accessed Oct. 2012].

Jiang J., Fei L. \& Huang Y. 2009. Aquixalus beibengensis Jiang, Fei \& Huang, sp. nov. In: Fei L., Hu S., Ye C. \& Huang Y. (eds) Fauna Sinica. Amphibia. Vol. 2. Anura: 708-711. Chinese Academy of Science, Science Press, Beijing.

Katoh K. \& Standley D.M. 2013. MAFFT multiple sequence alignment software, version 7: improvements in performance and usability. Molecular Biology and Evolution 30: 772-780.

https://oi.org/10.1093/molbev/mst010

Kunz K., Honigs S. \& Eisenberg T. 2010. Moosfrösche: die Gattung Theloderma. Natur und Tier Verlag, Münster, Germany.

Kuraishi N., Matsui M., Hamidy A., Belabut D.M., Ahmad N., Panha S., Sudin A.,Yong H.S., Jiang J.P., Ota H., Thong H.T. \& Nishikawa K. 2013. Phylogenetic and taxonomic relationships of the Polypedates leucomystax complex (Amphibia). Zoologica Scripta 42: 54-70.

https://doi.org/10.1111/j.1463-6409.2012.00562.x

Leaché A.D. \& Reeder T.W. 2002. Molecular systematics of the eastern fence lizard (Sceloporus undulatus): a comparison of parsimony, likelihood, and Bayesian approaches. Systematic Biology 51: 44-68. https://doi.org/10.1080/106351502753475871

Li C., Hou M., Yu G., Yan F., Li B., Jiang K., Li P. \& Orlov N.L. 2016. Rediscovery of Theloderma moloch (Amphibia: Anura: Rhacophoridae) from Southeast Tibet, China after 102 years. Russian Journal of Herpetology 23 (1): 41-54.

Li J.T., Che J., Murphy R.W., Zhao H., Zhao E.M., Rao D.Q. \& Zhang Y.P. 2009. New insights to the molecular phylogenetics and generic assessment in the Rhacophoridae (Amphibia: Anura) based on five nuclear and three mitochondrial genes, with comments on the evolution of reproduction. Molecular Phylogenetics and Evolution 53 (2): 509-522. https://doi.org/10.1016/j.ympev.2009.06.023.

Liem S.S. 1970. The morphology, systematics, and evolution of the Old World treefrogs (Rhacophoridae and Hyperoliidae). Fieldiana, Zoology 57: 1-145. https://doi.org/10.5962/bhl.title.2939 
Liu C.C. \& Hu S.Q. 1962. A herpetological report of Kwangsi. Acta Zoologica Sinica 14 (Supplement): $73-104$.

Matsui M., Shimada T. \& Sudin A. 2014. First record of the tree-frog genus Chiromantis from Borneo with the description of a new species (Amphibia, Rhacophoridae). Zoological Science 31: 45-51.

https://doi.org/10.2108/zsj.31.45

McLeod D.S. \& Ahmad N. 2007. A new species of Theloderma (Anura: Rhacophoridae) from southern Thailand and peninsular Malaysia. Russian Journal of Herpetology 14: 65-72.

Nguyen S.V., Ho C.T. \& Nguyen T.Q. 2009. Herpetofauna of Vietnam. Edition Chimaira, Frankfurt am Main, Germany.

Nguyen T.Q., Le M.D., Pham C.T., Nguyen T.T., Bonkowski M. \& Ziegler T. 2012. A new species of Gracixalus (Amphibia, Anura, Rhacophoridae) from northern Vietnam. Organisms Diversity \& Evolution 13: 203-214. https://doi.org/10.1007/s13127-012-0116-0

Nguyen T.Q., Pham C.T., Nguyen T.T., Ngo N.H. \& Ziegler T. 2016. A new species of Theloderma (Amphibia: Anura: Rhacophoridae) from Vietnam. Zootaxa 4168 (1): 171-186.

https://doi.org/10.11646/zootaxa.4168.1.10

Nguyen T.T., Le D.T., Nguyen S.H.L., Matsui M. \& Nguyen T.Q. 2014. First record of Philautus petilus Stuart and Heatwole, 2004 (Amphibia: Anura: Rhacophoridae) from Vietnam and its phylogenetic position. Current Herpetology 33: 112-120. https://doi.org/10.5358/hsj.33.112

Nguyen T.T., Matsui M. \& Eto K. 2015. Mitochondrial phylogeny of an Asian tree frog genus Theloderma (Anura: Rhacophoridae). Molecular Phylogenetics and Evolution 85: 59-67.

https://doi.org/10.1016/j.ympev.2015.02.003

Nguyen X.D., Nguyen X.N., Ngo X.T. \& Nguyen T.T. 2018. Biodiversity survey and assessment of mammals, birds, reptiles and amphibians in Cao Ma Po-Ta Van-Tung Vai forest, Quan Ba district, Ha Giang province. Technical Report: 1-67.

Orlov N.L. 2007. Cryptic species of amphibians from Vietnam and their importance for assessment of taxonomic diversity. Uspekhi Sovremennoi Biologii 127 (6): 612-621.

Orlov N.L. \& Ho C.T. 2005. A new species of Philautus from Vietnam (Anura: Rhacophoridae). Russian Journal of Herpetology 12: 135-142.

Orlov N.L., Dutta S.K., Ghate H.V. \& Kent Y. 2006. New species of Theloderma from Kon Tum Province (Vietnam) and Nagaland State (India) (Anura: Rhacophoridae). Russian Journal of Herpetology 13: $165-175$.

Orlov N.L., Poyarkov N.A., Vassilieva A.B., Ananjeva N.B., Nguyen T.T., Nguyen S.N. \& Geissler P. 2012. Taxonomic notes on rhacophorid frogs (Rhacophorinae: Rhacophoridae: Anura) of southern part of Annamite Mountains (Truong Son, Vietnam), with description of three new species. Russian Journal of Herpetology 19: 23-64.

Poyarkov N.A., Orlov N.L., Moiseeva A.V., Pawangkhanant P., Ruwangsuwan T., Vassilieva A.B., Galoyan E.A., Nguyen T.T. \& Gogoleva S.S. 2015. Sorting out moss frogs: mtDNA data on taxonomic diversity and phylogenetic relationships of the Indochinese species of the genus Theloderma (Anura, Rhacophoridae). Russian Journal of Herpetology 22 (4): 241-280.

Poyarkov N.A., Kropachev I.I., Gogoleva S.I. \& Orlov N.L. 2018. A new species of the genus Theloderma Tschudi, 1838 (Amphibia: Anura: Rhacophoridae) from Tay Nguyen Plateau, central Vietnam. Zoological Research 39: 156-180. https://doi.org/10.24272/j.issn.2095-8137.2018.018 
Qui S., Yu G.H., Lei B., Yi F., Zhang D.L., Dong Z.W., Li P.P., Orlov N.L. \& Mian H. 2018. First record of Theloderma gordoni Taylor, 1962 from Yunnan Province, China. Russian Journal of Herpetology 25 (1): 43-55. https://doi.org/10.30906/1026-2296-2018-25-1-43-55

RambautA. \& Drummond A. 2009. TRACER, version 1.5. Available from http://beast.bio.ed.ac.uk/Tracer [accessed 15 Nov. 2021].

Rowley J.J.L., Le D.T.T., Hoang H.D., Dau V.Q. \& Cao T.T. 2011. Two new species of Theloderma (Anura: Rhacophoridae) from Vietnam. Zootaxa 3098 (1): 1-20. https://doi.org/10.11646/zootaxa.3098.1.1

Simmons J.E. 2002. Herpetological collecting and collections management. Revised edition. Herpetological Circular 31: 1-153. Society for the Study of Amphibians and Reptiles, Ithaca, New York. Available from https://ssarherps.org/publications/books-pamphlets/herp-circulars-pdfs/ [accessed 16 Nov. 2021].

Smith M.A. 1924. New tree-frogs from Indo-China and the Malay Peninsula. Proceedings of the Zoological Society of London 1924: 225-234. https://doi.org/10.1111/j.1096-3642.1924.tb01499.x

Stuart B.L. \& Heatwole H.F. 2004. A new Philautus (Amphibia: Rhacophoridae) from northern Laos. Asiatic Herpetological Research 10: 17-21.

Tanabe A.S. 2011. Kakusan 4 and Aminosan: two programs for comparing nonpartitioned, proportional and separate models for combined molecular phylogenetic analyses of multilocus sequence data. Molecular Ecology Resources 11: 914- 921. https://doi.org/10.1111/j.1755-0998.2011.03021.x

Tavaré S. 1986. Some probabilistic and statistical problems in the analysis of DNA sequences. Lectures on Mathematics in the Life Sciences (American Mathematical Society) 17: 57-86.

Taylor E.H. 1962. The amphibian fauna of Thailand. University of Kansas Science Bulletin 43: 265-599. https://doi.org/10.5962/bhl.part.13347

Tschudi J.J. von. 1838. Classification der Batrachier mit Berücksichtigung der fossilen Thiere dieser Abtheilung der Reptilien. Petitpierre, Neuchâtel. https://doi.org/10.5962/bhl.title.4883

Vences M., Thomas M., Bonett R.M. \& Vieites D.R. 2005. Deciphering amphibian diversity through DNA barcoding: chances and challenges. Philosophical Transactions of the Royal Society B: Biological Sciences 360 (1462): 1859-1868. https://doi.org/10.1098/rstb.2005.1717

Wilkinson J.A., Drewes R.C. \& Tatum O.L. 2002. A molecular phylogenetic analysis of the family Rhacophoridae with an emphasis on the Asian and African genera. Molecular Phylogenetics and Evolution 24 (2): 265-273. https://doi.org/10.1016/S1055-7903(02)00212-9

Zhi Y.Y., Chatmongkon S., Fang Y., Nikolay A.P., Sang N.N., Hong M.C., Siriwadee C., Robert W.M. \& Jing C. 2016. Red River barrier and Pleistocene climatic fluctuations shaped the genetic structure of Microhyla fissipes complex (Anura: Microhylidae) in southern China and Indochina. Current Zoology 62 (6): 531-543. https://doi.org/10.1093/cz/zow042

Ziegler T., Tran D.T.A., Nguyen T.Q., Perl R.G.B., Wirk L., Kulisch M., Lehmann T., Rauhaus A., Nguyen T.T., Le Q.K. \& Vu T.N. 2014. New amphibian and reptile records from Ha Giang Province, northern Vietnam. Herpetology Notes 7: 185-201.

Manuscript received: 27 April 2021

Manuscript accepted: 2 November 2021

Published on: 16 February 2022

Section editor: Rudy Jocqué

Desk editor: Pepe Fernández 
Printed versions of all papers are also deposited in the libraries of the institutes that are members of the EJT consortium: Muséum national d'histoire naturelle, Paris, France; Meise Botanic Garden, Belgium; Royal Museum for Central Africa, Tervuren, Belgium; Royal Belgian Institute of Natural Sciences, Brussels, Belgium; Natural History Museum of Denmark, Copenhagen, Denmark; Naturalis Biodiversity Center, Leiden, the Netherlands; Museo Nacional de Ciencias Naturales-CSIC, Madrid, Spain; Real Jardín Botánico de Madrid CSIC, Spain; Zoological Research Museum Alexander Koenig, Bonn, Germany; National Museum, Prague, Czech Republic.

Appendix 1. Examined specimens.

Theloderma bicolor (Bourret, 1937)

VIETNAM • 2 đô; Lao Cai Province, Sa Pa District; IEBR 3740, 3741 • 1 đ; same collection data as for preceding; VNMN 3536•1 ô, 1 q; Lai Chau Province, Sin Ho District; VNMN 010811, 010821.

Theloderma corticale (Boulenger, 1903)

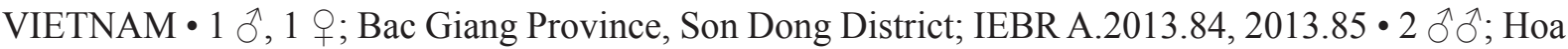
Binh Province, Lac Son District; IEBR 3758, 3759 • 1 đ, 1 o ; Vinh Phuc Province, Tam Dao District; VNMN 03556, J2892.

Theloderma gordoni Taylor, 1962

VIETNAM • 1 đ; Hoa Binh Province, Lac Son District; IEBR 3737 • 1 o, 1 o ; Vinh Phuc Province, Tam Dao NP; IEBR 3738, 3739.

Theloderma lateriticum Bain, Nguyen \& Doan, 2009

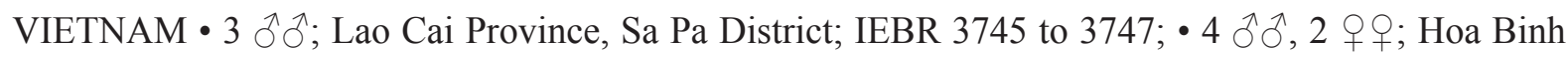
Province, Lac Son District; IEBR 3748 to 3753.

Theloderma truongsonense (Orlov \& Ho, 2005)

VIETNAM• 3 ふึ๋, 1 q; Quang Binh Province, Le Thuy District; IEBR 3754 to 3757.

Theloderma vietnamense Poyarkov, Orlov, Moiseeva, Pawangkhanant, Ruangsuwan, Vassilieva, Galoyan, Nguyen \& Gogoleva, 2015

VIETNAM • 3 ふै人; Kien Giang Province, Phu Quoc District; IEBR 3742 to 3744. 